\title{
TRINEXAPAC-ETHYL AFFECTS GROWTH AND GAS EXCHANGE OF UPLAND RICE $^{1}$
}

\author{
RITA DE CASSIA FÉLIX ALVAREZ ${ }^{2}$, CARLOS ALEXANDRE COSTA CRUSCIOL ${ }^{3}$, ADRIANO STEPHAN \\ NASCENTE $^{4}$, JOÃO DOMINGOS RODRIGUES ${ }^{5}$, GUSTAVO HABERMANN ${ }^{6}$, VESPASIANO BORGES DE PAIVA \\ $\mathrm{NETO}^{2}$
}

\begin{abstract}
A major problem affecting some upland rice cultivars is the increase in plant size when subjected to high doses of nitrogen fertilizer, leading to high levels of lodging. A method to reduce the height of upland rice, and therefore lodging, would be to use plant growth regulators. However, little information exists on the effect of these regulators on plant physiological processes. Therefore, the objective of this study was to evaluate the influence of trinexapac-ethyl application in upland rice via analysis of growth and gas exchange. The experiment was carried out under greenhouse conditions using the BRS Primavera cultivar. A completely randomized design with eight replications was used. Treatments were carried out with and without the application of the plant growth regulator, and plants were subject to two-stage assessments in which physiological and gas-exchange indices were measured. The use of trinexapac-ethyl improved the growth of rice plants from the flowering to the physiological maturity stage, resulting in higher values of leaf area ratio, specific leaf area, and leaf matter ratio in treated plants. At the same time, it provided smaller reduction in net $\mathrm{CO}_{2}$ assimilation at the physiological maturity stage. Thus, net/apparent assimilation rate did not change after the application of growth regulator, but relative growth rate decreased in these treated plants. These results indicate the occurrence of self-shading in rice plants induced by what might be a supra-optimum trinexapacethyl concentration.
\end{abstract}

Keywords: Oryza sativa. Growth regulator. Physiological process.

\section{ETIL-TRINEXAPAC AFETANDO O CRESCIMENTO E AS TROCAS GASOSAS DO ARROZ DE TERRAS ALTAS}

RESUMO - Um dos grandes problemas de alguns cultivares de arroz de terras altas é o aumento do porte da planta quando submetido a altas doses de fertilizante nitrogenado, atingindo altos índices de acamamento. Uma opção para diminuir a altura das plantas de arroz, e com isso também o acamamento, seria a utilização de reguladores vegetais, entretanto, existem poucas informações sobre o efeito desses reguladores nos processos fisiológicos da planta. Assim, objetivou-se, por meio da análise de crescimento e de trocas gasosas, avaliar a influência da aplicação de etil-trinexapac na cultura do arroz de terras altas. $\mathrm{O}$ experimento foi conduzido em casa-de-vegetação usando-se a cultivar BRS Primavera. Foi utilizado o delineamento experimental inteiramente casualizado, com oito repetições. Os tratamentos foram constituídos sem e com aplicação de regulador de crescimento vegetal e dois estádios de desenvolvimento avaliados. Foram estimados os índices fisiológicos e trocas gasosas. $\mathrm{O}$ uso de regulador de crescimento etil-trinexapac proporcionou melhor desenvolvimento das plantas de arroz do estádio de florescimento a maturação físiológica, resultando em valores de RAF, AFE e PMF mais elevados nas plantas tratadas. Paralelamente, proporcionou menor redução na assimilação líquida de $\mathrm{CO}_{2}$ na fase de maturação fisiológica. Assim, a TAL não sofreu alteração em função do regulador de crescimento e a TCR apresentou redução nas plantas tratadas. Estes resultados indicam a ocorrência de autosombreamento na cultura induzida pela concentração do etil-trinexapac, que pode ter sido supra ótima.

Palavras-chave: Oryza sativa. Regulador de crescimento. Processo fisiológico.

\footnotetext{
*Corresponding author

${ }^{1}$ Received for publication in $10 / 30 / 2014$; accepted in $01 / 25 / 2016$.

Paper extracted from the doctoral thesis of the first author.

${ }^{2}$ Departament of Agronomy, Universidade Federal do Mato Grosso do Sul. Chapadão do Sul, MS, Brazil; rita.alvarez@ufms.br, vespasiano.neto@ufms.br.

${ }^{3}$ Department of Production and Plant Breeding, School of Agronomic Sciences, Universidade Estadual Paulista, Botucatu, SP, Brazil; crusciol@fca.unesp.br.

${ }^{4}$ Embrapa Arroz e Feijão, Santo Antônio de Goiás, GO, Brazil; adriano.nascente@embrapa.br.

${ }^{5}$ Department of Botany, Institute of Biosciences, Universidade Estadual Paulista, Botucatu, SP, Brazil; mingo@ibb.unesp.br.

${ }^{6}$ Department of Botany, Institute of Biosciences, Universidade Estadual Paulista, Rio Claro, SP, Brazil; ghaber@rc.unesp.br
} 


\section{INTRODUCTION}

Rice (Oryza sativa L.) is one of the major cereal crops planted worldwide, and has great social and economic importance for the Brazilian population (NAVES; BASSINELLO, 2006; NASCENTE et al., 2011). Upland rice crops occupy about $65 \%$ of the total cultivated area in Brazil. However, grain yield is low, representing only $41 \%$ of national production (CONAB, 2011). The lower yield of upland rice than of irrigated rice is mainly due to the uneven distribution of rainfall, which negatively affects the stages of plant growth in which water supply is crucial (GUIMARÃES et al., 2010). With the use of irrigation, rice plants are not subjected to water stress, and as a result, grain filling is not influenced by drought. Thus, the number of spikelets per panicle and the grain weight are greater than in upland rice (ARF et al., 2002; CRUSCIOL et al., 2006).

A major problem observed in upland rice is the increase in plant size when it is subjected to high doses of fertilizer, which can cause high indices of lodging in some cultivars (NASCIMENTO et al., 2009; FAGERIA; MORAES; VASCONCELOS, 2011). One strategy to reduce the height of rice plants, and thus lodging, would be to use plant growth regulators (NASCIMENTO et al., 2009). These are synthetic compounds used to reduce the unwanted longitudinal growth of shoots without reducing grain yield (RADEMACHER, 2000; TAIZ ; ZEIGER, 2009).

Trinexapac-ethyl is a regulator designed to be used as an anti-lodging agent in cereals and grasses and as a growth regulator in lawns (FIALHO et al., 2009; TAIZ; ZEIGER, 2009). In Brazil, this product is used as a sugarcane ripener, as it promotes increased sugar yield without negatively affecting juice quality, fiber content, or cane weight (RESENDE; SOARES; HUDETZ, 2001; VIANA et al., 2008). Trinexapac-ethyl has also been successfully used in wheat crops to reduce plant height to prevent lodging (ZAGONEL; FERNANDES, 2007; TREVIZAN; GREGOLETI; HOFFMANN, 2015). However, little information is available regarding the effect of the application of plant growth regulators on the physiological processes of upland rice crops (BUZETTI et al., 2006; NASCIMENTO et al., 2009; ALVAREZ et al., 2012, 2014).

Growth analysis is a technique that analyzes a plant's morphological and physiological changes as functions of time. The technique also assesses photosynthetic production by means of dry matter accumulation, allowing a better understanding of the factors that affect grain yield (URCHEI; RODRIGUES; STONE, 2000; FALQUETO et al., 2009; ALVAREZ; CRUSCIOL; NASCENTE, 2012a; OLIVEIRA et al., 2013). Furthermore, grain yield in rice and other cereals is related to the amount of $\mathrm{CO}_{2}$ fixed by the plant and to the partitioning of the photosynthesized substrate for the growth of grains and of other plant organs (TAIZ; ZEIGER, 2009; CONCENÇO et al., 2011; FAGERIA; MORAES; VASCONCELOS, 2011).Thus, the objective of this study was to assess the influence of the application of trinexapac-ethyl on upland rice crops through the analysis of plant growth and gas exchange.

\section{MATERIAL AND METHODS}

The experiment was carried out in greenhouses at the Department of Plant ProductionAgriculture at the Experimental Farm Lageado (FEL), belonging to the School of Agricultural Sciences-FCA, Botucatu Campus, University of the State of São Paulo (UNESP) in the municipality of Botucatu, SP. The experimental setup used a completely randomized design in a factorial $2 \times 4$ with eight replications. Treatments consisted of a combination of the following factors: Growth Regulator (1 - without, 2 - with) and Developmental Stage (1 - flowering, 2 - physiological maturity.).

Each plot was represented by a pot with two plants of BRS Primavera. We used two plants with $15 \mathrm{~L}$ of nutrient solution per pot, following the methodology proposed by Furlani and Furlani (1988).

Trinexapac-ethyl was applied following the manufacturer's recommendation (200 $\mathrm{g} \mathrm{ha}^{-1}$ active ingredient), at the primordia panicle differentiation stage, as a directed spray, with a knapsack sprayer calibrated at a constant $\mathrm{CO}_{2}$ pressure with a TX-VS2type full-cone nozzle and approximately $100 \mathrm{~L} \mathrm{ha}^{-1}$ of syrup. The regulator solution was prepared with nonionic surfactant $\left(0.05 \%, 0.5 \mathrm{~mL} \mathrm{~L}^{-1}\right)$ and urea $(1.0 \%)$ for better adhesion and absorption.

Data collection for growth analysis was carried out at four developmental stages: tillering (37 $\mathrm{DAE})$, primordia panicle differentiation (49 DAE), flowering (63 DAE), and physiological maturity (125 DAE). Data from eight pots (four without and four with growth regulator) were collected in each collection stage. Two plants per pot were sampled.

Collected plants had their parts separated as follows: roots, green leaves, stem + sheath, and panicles. Leaf area of the two plants in the pot was then measured with the aid of a leaf area meter (AAM-7 model, Hayashi, Denkoh CO). The dry matter of each organ was obtained by drying the plant at $60{ }^{\circ} \mathrm{C}$ in an oven with forced air circulation until a constant weight was attained.

The following physiological indices were estimated: relative growth rate (RGR), net/apparent assimilation rate (NAR), leaf area ratio (LAR), specific leaf area (SLA), and leaf matter ratio (LMR), using the ANACRES software (PORTES; CASTRO JÚNIOR, 1991). 
Gas exchange measures were carried out using a LI-6400 (Licor Inc. Lincoln, NE) portable photosynthesis open system, which measures $\mathrm{CO}_{2}$ and water stem concentrations by infrared radiation, following the methodology proposed by Machado and Lagôa (1994) and Concenço et al. (2011). Since gas exchange assessment is better during the greatest photosynthetic photon flux density (PPFD) and before the air temperature reaches the limit values for plants with the $\mathrm{C} 3$ photosynthetic mechanism (FEISTLER; HABERMANN, 2012; ALVAREZ et al., 2015), plants were evaluated between 9 am and $11 \mathrm{am}$. Measurements were taken under natural fluctuation in PPFD, and ranged between 700 and $1400 \mu \mathrm{mol} \mathrm{m} \mathrm{m}^{-2} \mathrm{~s}^{-1}$. Air temperature ranged between 30.9 and $31.9^{\circ} \mathrm{C}$, and humidity ranged between 60.7 and $62.6 \%$

Measurements were carried out using fully expanded leaves at the developmental stages (tillering and primordia panicle differentiation stage) and using the flag leaf at the flowering and physiological maturity stages. In all treatments, one leaf per plot was chosen, and measurements were carried out in the middle region of the fullyexpanded leaf. Each leaf was allowed to rest in the chamber for 1-2 min before values were recorded.

The measured parameters were $\mathrm{CO}_{2}$ net assimilation rate (A), in $\mu \mathrm{mol} \mathrm{m} \mathrm{m}^{-2} \mathrm{~s}^{-1}$, stomatal conductance $\left(\mathrm{g}_{\mathrm{s}}\right)$, in $\mathrm{mmol} \mathrm{m} \mathrm{m}^{-2} \mathrm{~s}^{-1}$, and transpiration (E), in mol m $\mathrm{m}^{-2} \mathrm{~s}^{-1}$. Additionally, we calculated instantaneous water use efficiency (WUE) using the ratio $(\mathrm{W} / \mathrm{E})$.

Growth analysis and gas exchange data were subjected to analysis of variance, and treatment means were compared using the LSD test at 5\%, considering the two factors (growth regulator and development stage).

\section{RESULTS AND DISCUSSION}

Plants without growth regulator treatment had higher RGR at the flowering stage; RGR values decreased at 125 DAE owing to physiological maturity and to leaf fall and death during senescence (Table 1). In plants treated with trinexapac-ethyl, the RGR value was also lower at the physiological maturity stage than at the flowering stage. This downward trend in the relative growth rate as a function of the plant's age is in accordance with the observations of Stone, Portes and Moreira (1988), and Falqueto et al. (2009) in rice plants. According to Taiz and Zeiger (2009), RGR reflects the increase in plant dry matter of any organ over a period of time and is a function of the initial size, i.e., of the preexisting material.

RGR reduction is usually related to accumulated dry matter production during plant development, together with the decreased relative ability of the crop to produce new biomass
(ANTONIAZZI; DESCHAMPS, 2006; ALVAREZ; CRUSCIOL; NASCENTE, 2012). In addition, increased respiratory activity during plant development and self-shadowing can also decrease RGR (URCHEI; RODRIGUES; STONE, 2000), as observed in this experiment. At the end of the plant cycle, RGR is negative due to the death of leaves and buds and to the gradual production of nonassimilatory tissues (MILTHORPE; MOORBY, 1974; FALQUETO et al., 2009), as observed in this trial both with and without growth regulator application (Table 1). Alvarez, Crusciol and Nascente (2012), working with BRS Primavera under field conditions, also observed a steady reduction in RGR with increase in DAE. The authors attributed this behavior to the fall and death of leaves with the advancement of plant development and gradual increase in non-assimilatory tissues. In another study with the same cultivar, also under field conditions, Alvarez et al. (2015) reported that after 57 DAE, BRS Primavera begins to show reduced $\mathrm{CO}_{2}$ assimilation, transpiration, and stomatal conductance, which may also explain the reduction of RGR values after this period.

NAR was lower in both treatments at the physiological maturity stage than at the flowering stage (Table 1) because of leaf fall and death during senescence. Moreover, NAR values were higher at flowering probably due to the increased efficiency of photosynthesis in leaves at this stage, thus allowing the estimate of net photosynthesis (FAGERIA; MORAES; VASCONCELOS, 2011). Similar results were observed by Stone, Portes and Moreira (1988), Antoniazzi and Deschamps (2006), Falqueto et al. (2009), and Fageria, Moraes and Vasconcelos (2011)

LAR represents the relative size of the photosynthetic apparatus and is well suited to the assessment of genotypic and climatic effects on plant communities (ANTONIAZZI; DESCHAMPS, 2006). This physiological index expresses the area of the leaf useful for photosynthesis and can serve as a morphophysiological component of growth analysis (CAMPOS et al., 2008). Generally, LAR tends to decrease as the plant grows, since growth promotes a reduction in useful leaf area after a certain stage. Likewise, lower LAR values were observed, regardless of the treatment, at physiological maturity stage than at the flowering stage (Table 1). After flowering, LAR values were lower mainly due to the presence of non-assimilatory tissues and structures, in addition to self-shadowing, senescence, and leaf fall (URCHEI; RODRIGUES; STONE, 2000; FALQUETO et al., 2009). At the physiological maturity stage, higher LAR values were observed in treatments with growth regulator application than in treatment without growth regulator. This indicates that treatment with the plant growth regulator results in a greater leaf area ratio, which can help increase yield, since the leaf area index (LAI) does not 
exceed the optimum leaf area, which would result in auto-shading and in reduction of NAR and yield.

Specific leaf area (SLA) did not differ between treatments and was lower in both treatments at the physiological maturity stage than at the flowering stage (Table 1). This indicates that, at the concentration used, trinexapac-ethyl-treated plants produced greater leaf area than non-treated plants. Results observed by Aguiar Neto et al. (2000) in potato, by Silva et al. (2005) in sugarcane, and by Falqueto et al. (2009) in rice show that similar reductions in SLA are due to the translocation of reserves from leaves to other parts of the plant, such as stalks.

Table 1. Relative growth rate (RGR), net assimilation rate (NAR), leaf area ratio (LAR), specific leaf area (SLA), and leaf matter ratio (LMR) of upland rice plants over two assessment periods, and the effect of the application of trinexapac-ethyl in the primordia panicle on the above variables at flowering and physiological maturity stages.

\begin{tabular}{|c|c|c|}
\hline \multirow{2}{*}{$\begin{array}{l}\text { Trinexapac-ethyl } \\
\left(200 \mathrm{~g} \mathrm{ha}^{-1}\right)\end{array}$} & \multicolumn{2}{|c|}{ Developmental stages } \\
\hline & Flowering (63 DAE*) & Physiological maturation (125 DAE) \\
\hline & \multicolumn{2}{|c|}{$\underline{\operatorname{RGR}\left(\mathrm{g} \mathrm{g}^{-1} \text { day }^{-1}\right)}$} \\
\hline Without & $0.0859 \mathrm{aA}^{* *}$ & $-0.0330 \mathrm{bB}$ \\
\hline With & $0.0897 \mathrm{aA}$ & $-0.0417 \mathrm{aB}$ \\
\hline & \multicolumn{2}{|c|}{$\operatorname{NAR}\left(\mathrm{g} \mathrm{dm}^{-2} \mathrm{day}^{-1}\right)$} \\
\hline Without & $0.1244 \mathrm{aA}$ & $-0.1242 \mathrm{aB}$ \\
\hline With & $0.1218 \mathrm{aA}$ & $-0.1291 \mathrm{aB}$ \\
\hline & & \\
\hline Without & $0.6904 \mathrm{aA}$ & $0.2659 \mathrm{bB}$ \\
\hline With & $0.7369 \mathrm{aA}$ & $0.3228 \mathrm{aB}$ \\
\hline & & \\
\hline Without & $2.0424 \mathrm{aB}$ & $1.6660 \mathrm{aC}$ \\
\hline With & $2.1316 \mathrm{aA}$ & $1.7091 \mathrm{aB}$ \\
\hline & & \\
\hline Without & $0.2494 \mathrm{aC}$ & $0.1597 \mathrm{bD}$ \\
\hline With & $0.2605 \mathrm{aA}$ & $0.1901 \mathrm{aB}$ \\
\hline
\end{tabular}

${ }^{*} \mathrm{DAE}=$ days after emergence. ${ }^{* *}$ Values followed by the same uppercase letter in the row (developmental stages), and lowercase letter in the column (growth regulator) do not differ by the LSD test at $5 \%$ probability.

We also verified high leaf matter values (LMR at the flowering stage. After this period, LMR values were lower at the end of the cycle in both treatments. Plants treated with the growth regulator produced higher values than plants not treated with growth regulator at the physiological maturity stage (Table 1). High values of LMR indicate greater allocation of assimilates in leaves under development and in new leaves, which are preferential metabolic sinks (ZEPKA; LARRÉ; LOPES, 2007; FALQUETO et al., 2009; FAGERIA; MORAES; VASCONCELOS, 2011). On the other hand, the reduction of these values indicates the allocation of these photoassimilates to other parts of the plant (LUGG; SINCLAIR, 1980).

These results demonstrate that the application of plant growth regulator at the primordia panicle differentiation stage increased the physiological indices RGR, LAR, and RPF when assessed at the flowering and physiological maturity stages (Table 1). It is noteworthy that trinexapac-ethyl is associated with inhibiting gibberellin synthesis. Gibberellins are responsible for increasing cells number and length, thereby affecting growth, especially in the stem (NASCIMENTO et al. 2009). Thus, the least sharp decline of the above-mentioned physiological indices may be associated with the action of the growth regulator. Therefore, it can be inferred that the application of trinexapac-ethyl at the primordia panicle differentiation stage at the used dosage did not cause vegetative damage to plants. Instead, it produced higher values of LAR and RPF, which could result in increased yields. Furthermore, Buzetti et al. (2006) did not observe decreased yield with the application of plant growth regulators in rice. Similar studies, all of which determined that plant growth regulators application did not damage the crops, were conducted by Urchei, Rodrigues and Stone (2000), Resende, Soares and Hudetz (2001), Silva et al. (2005), Zagonel and Fernandes (2007), Campos et al. (2008), Viana et al. (2008), Fialho et al. (2009), and Martins et al. (2014).

We also determined that trinexapac-ethyl influenced gas exchange rates when applied at the primordia panicle differentiation stage (Table 2). Higher values of $\mathrm{CO}_{2}$ assimilation rate, instantaneous water use efficiency, transpiration, and stomatal conductance were observed at the flowering stage than at physiological maturity. These results may help explain the growth rate values obtained when trinexapac-ethyl was applied, resulting in higher $\mathrm{CO}_{2}$ net assimilation rate without influencing RGR and NAR (Table 1). Therefore, there was a trend that the assimilates resulting from higher net assimilation rate in leaf tissue were used, as shown by the data on the leaf area of treated plants, which explains the increased values of LAR, SLA, total leaf dry matter, and total dry matter. 
Table 2. $\mathrm{CO}_{2}$ net assimilation, stomatal conductance, transpiration, and instantaneous efficiency of water use $\left(\mathrm{CO}_{2}\right.$ net assimilation/transpiration) for upland rice plants over two assessment periods and the effect of application of trinexapacethyl in primordia panicle differentiation on the above variables at the flowering and physiological maturity stages.

\begin{tabular}{|c|c|c|}
\hline \multirow{2}{*}{$\begin{array}{l}\text { Trinexapac-ethyl } \\
\left(200 \mathrm{~g} \mathrm{ha}^{-1}\right)\end{array}$} & \multicolumn{2}{|c|}{ Developmental stages } \\
\hline & Flowering (63 DAE*) & Physiological maturation (125 DAE) \\
\hline & \multicolumn{2}{|c|}{$\mathrm{CO}_{2}$ net assimilation $\left(\mu \mathrm{mol} \mathrm{m}{ }^{-2} \mathrm{~s}^{-1}\right)$} \\
\hline Without & $22.50 \mathrm{aA} * *$ & $12.07 \mathrm{bB}$ \\
\hline With & \multicolumn{2}{|c|}{ Transpiration $\left(\mathrm{mmol} \mathrm{m}^{-2} \mathrm{~s}^{-1}\right)$} \\
\hline Without & $6.5 \mathrm{bA}$ & $5.2 \mathrm{bB}$ \\
\hline With & \multicolumn{2}{|c|}{ Stomatal conductance $\left(\mathrm{mol} \mathrm{m}^{-2} \mathrm{~s}^{-1}\right)$} \\
\hline Without & $0.78 \mathrm{bA}$ & $0.31 \mathrm{bB}$ \\
\hline With & $0.89 \mathrm{aA}$ & $0.34 \mathrm{aB}$ \\
\hline \multicolumn{3}{|c|}{ Instantaneous efficiency of water use $\left(\mu \mathrm{mol} \mathrm{m}{ }^{-2} \mathrm{~s}^{-1} / \mathrm{mmol} \mathrm{m}^{-2} \mathrm{~s}^{-1}\right)$} \\
\hline Without & $3.59 \mathrm{aA}$ & $2.36 \mathrm{bC}$ \\
\hline With & $3.28 \mathrm{bA}$ & $2.72 \mathrm{aB}$ \\
\hline
\end{tabular}

${ }^{*} \mathrm{DAE}=$ days after emergence. ${ }^{* *}$ Values followed by the same uppercase letter in the row (developmental stages), and lowercase letter in the column (growth regulator) do not differ by the LSD test at 5\% probability.

Finally, reduction in NAR and RGR, resulting from trinexapac-ethyl application at $200 \mathrm{~g} \mathrm{ha}^{-1}$, may indicate crop selfshading. This scenario would likely result in reduced crop yield, as demonstrated by Alvarez et al (2007). Nascimento et al. (2009), using the same genetic material as that used in our study but in field conditions, found that the concentration of trinexapac-ethyl may cause a reduction in rice yield when applied in supra-optimum concentrations. The highest $(3.59 \mu \mathrm{mol} \mathrm{CO}$ $\left.\mathrm{m}^{-2} \mathrm{~s}^{-1} / \mathrm{mmol} \mathrm{H}_{2} \mathrm{O} \mathrm{m}^{-2} \mathrm{~s}^{-1}\right)$ and lowest (2.36 $\mu \mathrm{mol} \mathrm{CO} \mathrm{Cm}_{2}^{-2} \mathrm{~s}^{-1} / \mathrm{mmol} \mathrm{H}_{2} \mathrm{O} \mathrm{m}^{-2} \mathrm{~s}^{-1}$ ) values of WUE were obtained at the stages of flowering and physiological maturity, respectively, of plants without trinexapacethyl application (Table 2). This is because plants treated with trinexapac-ethyl present lower reduction in $\mathrm{CO}_{2}$ net assimilation during the physiological maturity stage, even if they have higher transpiration values than non-treated plants. Thus, this reduction in WUE has an inverse correlation with the highest transpiration $\left(7.0 \mathrm{mmol} \mathrm{m} \mathrm{m}^{-2} \mathrm{~s}^{-1}\right)$ generated by greater stomatal conductance $\left(890 \mathrm{mmol} \mathrm{m}^{-2} \mathrm{~s}^{-1}\right)$ in non-treated plants.

\section{CONCLUSIONS}

Trinexapac-ethyl did not favor net assimilation rate and relative crop growth at the reproductive stage.
Greater leaf area at the flowering and physiological maturity stages resulted in crop self-shading after trinexapac-ethyl application.

\section{ACKNOWLEDGEMENTS}

The authors thank Fapesp for the financial support of this research (Proc. \#2000/02748-2), and CNPq for the productivity fellowship granted to the second author.

\section{REFERENCES}

AGUiAR NETTO, A. O.; RODRIGUES, J. D.; PINHO, S. Z. Análise de crescimento na cultura da batata submetida a diferentes lâminas de irrigação. Pesquisa Agropecuária Brasileira, Brasília, v. 35, n. 5, p.901-907, 2000.

ALVAREZ, R. C. F.; CRUSCIOL, C. A. C.; NASCENTE, A. S. Análise de crescimento e produtividade de cultivares de arroz de terras altas dos tipos tradicional, intermediário e moderno. Pesquisa Agropecuária Tropical, Goiânia, v. 42, n. 4, p. 397-406, 2012a.

ALVAREZ, R. C. F. et al. Gas exchange rates, plant height, yield components, and productivity of upland rice as affected by plant regulators. Pesquisa Agropecuária Brasileira, Brasília, v. 47, n. 10, p. 1455-1461, 2012b.

ALVAREZ, R. C. F.; CRUSCIOL, C. A. C.; NASCENTE, A. S. Produtividade de arroz de terras 
altas em função de reguladores de crescimento. Revista Ceres, Viçosa, v. 61, n. 1, p. 42-49, 2014.

ALVAREZ, R. C. F. et al. Leaf gas exchange and yield of three upland rice cultivars. Bragantia, Campinas, v. 74, n. 1, p. 1-8, 2015.

ALVAREZ, R. C. F. et al. influência do etiltrinexapac no acúmulo, na distribuição de nitrogênio $\left({ }^{15} \mathrm{~N}\right)$ e na massa de grãos de arroz de terras altas. Revista Brasileira de Ciência do Solo, Viçosa, v. 3, n. 6, 1487-1496, 2007.

ANTONIAZZI, N.; DESCHAMPS, C. Análise de crescimento de duas cultivares de cevada após tratamentos com elicitores e fungicidas. Ciência Rural, Santa Maria, v. 36, n. 4, p. 1065-1071, 2006.

ARF, O. et al. Preparo do solo, irrigação por aspersão e rendimento de engenho do arroz de terras altas. Scientia Agricola, Piracicaba, v. 59, n. 2, p. 321-356, 2002.

BUZETTI, S. et al. Resposta de cultivares de arroz a doses de nitrogênio e do regulador de crescimento cloreto de clormequat. Pesquisa Agropecuária Brasileira, Brasília, v. 41, n. 12, p. 1731-1737, 2006.

CAMPOS, M. F. et al. Análise de crescimento em plantas de soja tratadas com substâncias reguladoras. Revista Biotemas, Florianópolis, v. 21, n. 3, p. 5363, 2008 .

CAPPELLARI, I. Genótipos de trigo (Triticum aestivum L.) submetidos a aplicação de Trinexapacethyl em diferentes densidades de semeadura. 2011. 40 f. Graduação. Universidade Regional do noroeste do estado do Rio Grande do Sul, UNIJUI. Ijuí, RS. Disponível em: http:// bibliodigital.unijui.edu.br:8080/xmlui/bitstream/ handle/123456789/700/iurguestcc.pdf? sequence $=1$. Acesso em: 8 nov 2015.

COMPANHIA NACIONAL DE ABASTECIMENTO - CONAB. $4^{\circ}$ Levantamento da produção de grãos - safra 2010/11. Disponível em:<www.conab.gov.br>. Acesso em: 05 de dez. 2011.

CONCENÇO, G. I. et al. Photosynthetic characteristics of hybrid and conventional rice plants as a function of plant competition. Planta Daninha, Viçosa, v. 29, n. 4, p. 803-809, 2011.

CRUSCIOL, C. A. C. et al. Yield of upland rice cultivars in rainfed and sprinkler-irrigated systems in the Cerrado region of Brazil. Australian Journal of Experimental Agriculture, Collingwood, v. 46, n. 9, p. 1515-1520, 2006
FAGERIA, N. K.; MORAES, O. P.; VASCONCELOS, M. J. Yield and yield components of upland rice as influenced by nitrogen sources. Journal of Plant Nutrition, Philadelphia, v. 34, n. 1, p. 361-370, 2011.

FALQUETO, A. R. et al. Partição de assimilados em cultivares de arroz diferindo no potencial de produtividade de grãos. Bragantia, Campinas, v. 68 , n. 3, p. 453-461, 2009.

FEISTLER, A. M.; HABERMANN G. Assessing the role of vertical leaves within the photosynthetic function of Styrax camporum under drought conditions. Photosynthetica, Praha Czech Republic, v. 50, n. 4, p. 613-622, 2012.

FIALHO, C. M. T. et al. Caracteres morfoanatômicos de Brachiaria brizantha submetida à aplicação de Trinexapac-Ethyl. Planta Daninha, Viçosa, v. 27, n. 3, p. 533-539, 2009.

FURLANI, A. M. C.; FURLANI, P. R. Composição e pH de soluções nutritivas para estudos fisiológicos e seleção de plantas em condições nutricionais adversas. Campinas: Instituto Agronômico, 1988. 34 p. (Boletim Técnico, 121).

GUimarÃES, C. M. et al. Desempenho de genótipos de arroz sob deficiência hídrica e irrigação adequada. Santo Antônio de Goiás: Embrapa Arroz e Feijão, 2010, 4 p. (Comunicado Técnico, 194).

LUGG, D. G.; SINCLAIR, T. R. Seasonal changes in morphology and anatomy of field grown soybean leaves. Crop Science, Madison, v. 20, n. 2, p. 191196,1980

MACHADO, E. C.; LAGÔA, A. M. M. A. Trocas gasosas e condutância estomática em três espécies de gramíneas. Bragantia, Campinas, v. 53, n. 2, p. 141 149,1994

MARTINS, L. M. et al. Épocas de aplicação de regulador de crescimento e de sombreamento artificial em cultivares de trigo. Revista Eixo, Brasília, v. 3, n. 1, p. 47-59, 2014.

MILTHORPE, F. L.; MOORBY, J. An introduction to crop physiology. Cambridge, Grã-Bretanha: Cambridge University, 1974. 201 p.

NASCENTE, A. S. et al. Produtividade do arroz de terras altas em função do manejo do solo e da época de aplicação de nitrogênio. Pesquisa Agropecuária Tropical, Goiânia, v. 41, n. 1, 60-65, 2011.

NASCIMENTO, V. et al. Uso do regulador de crescimento etil-trinexapac em arroz de terras altas. 
Bragantia, Campinas, v. 68, n. 4, p. 921-929, 2009.

NAVES, M. M. V.; BASSINELlO, P. Z. Importância na nutrição humana. In: SANTOS, A. B.; STONE, L. F.; VIEIRA, N. R. A. A cultura do arroz no Brasil. 2 Ed. Santo Antônio de Goiás: Embrapa Arroz e Feijão, 2006, p.17-30.

OLIVEIRA, P. et al. Crescimento e produtividade do milho em função da cultura antecessora. Pesquisa Agropecuária Tropical, Goiânia, v. 43, n. 3, p. 239246, 2013.

PORTES, T. A.; CASTRO JÚNIOR, L. G. Análise de crescimento de plantas: um programa computacional auxiliar. Revista Brasileira de Fisiologia Vegetal, Campinas, v. 3, n. 1, p. 53-56, 1991.

RADEMACHER, W. Growth retardants: effects on gibberellin biosynthesis and other metabolic pathways. Annual Review of Plant Physiology and Plant Molecular Biology, Palo Alto, v. 51, n. 3, p. 501-531, 2000.

RESENDE, P. A. P.; SOARES, J. E.; HUDETZ, M. Moddus, a plant growth regulator and management tool for sugarcane production in Brasil. International Sugar Journal, London, v. 103, n. 1225, p. 2-6, 2001.

SILVA, D. K. T. et al. Análise de crescimento em cultivares de cana-de-açúcar em Cana-Soca no Noroeste do Paraná na safra de 2002/2003. Scientia Agraria, Curitiba, v. 6, n. 1-2, p. 47-53, 2005.

STONE, L. F.; PORTES, T. A.; MOREIRA, J. A. A. Efeitos da tensão de água do solo sob a produtividade e crescimento do feijoeiro. II. Crescimento. Pesquisa Agropecuária Brasileira, Brasília, v. 23, n. 5, p. 503-510, 1988.

TAIZ, L.; ZEIGER, E. Fisiologia vegetal. 4. ed. Porto Alegre, RS: ARTMED, 2009. 618 p.

TREVIZAN, K.; GREGOLETI, E.; HOFFMANN, A. F. Trinexapac-etil diminui o acamamento e aumenta produtividade do cultivar de trigo Tbio Pioneiro. Ramvi, Getúlio Vargas, v. 2, n. 3, p. 1-11, 2015.

URCHEI, M. A.; RODRIGUES, J. D.; STONE, L. F. Análise de crescimento de duas cultivares de feijoeiro sob irrigação, em plantio direto e preparo convencional. Pesquisa Agropecuária Brasileira, Brasília, v. 35, n. 3, p. 497-506, 2000.

VIANA, R. S. et al. Efeito da aplicação de maturadores químicos na cultura da cana de açúcar. Acta Scientiarum Agronomy, Maringá, v. 30, n. 1, p. $65-71,2008$.
ZAGONEL, J.; FERNANDES, E. C. Doses e épocas de aplicação de redutor de crescimento afetando cultivares de trigo em duas doses de nitrogênio. Planta Daninha, Viçosa, v. 25, n. 2, p. 331-339, 2007.

ZAGONEL J. et al. Doses de nitrogênio e densidades de plantas com e sem regulador de crescimento afetando o trigo, Cultivar OR-1. Ciência Rural, Santa Maria, v. 32, n. 1, p. 25-29, 2002.

ZEPKA, A. P. S.; LARRÉ, C. F.; LOPES, N. F. Efeito do herbicida pendimethalin na germinação de sementes de trigo. Revista Brasileira de Biociências, Porto Alegre, v. 5, n. 2, p. 630-632, 2007. 